\title{
Sourses of Criminal Law of some European Countries and Rules for the Application of Criminal Law in Time
}

\section{Zayniddin Ziyoviddinovich Shamsiddinov}

Lecturer of the Department of Criminal law, Criminology and Fight against Corruption of Tashkent State University of Law, z.shamsiddinov@tsul.uz

\begin{abstract}
This article discusses the sources of criminal law in some European countries and the rules of timely application of criminal law. Study of different areas of law, legal institutions and legal norms in a legal system will help to find a solution to such issues that legal science and the legislature had to decide in particular issues related to the temporal application of criminal law.

According to the Article 1 of the Criminal Code of the Republic of Uzbekistan the criminal legislation of the Republic of Uzbekistan is based on the Constitution and generally recognized norms of international law and consists of this Code[1]. From this it is clear that the only source of criminal law is the criminal code.

Keywords: international law, Criminal Code, Criminal legislation, French Penal Code, Fight against Illegal Work.
\end{abstract}

Article Received: 10 August 2020, Revised: 25 October 2020, Accepted: 18 November 2020

\section{Introduction}

Article 13 of the Criminal Code of the Republic of Uzbekistan regulates the operation of the criminal law in time.The criminality and punishability of the act is determined by the law in force at the time of the commission of the act. The time when the crime was committed is the time when the act was committed or the consequence occurred. The new law has retroactive effect if it eliminates the criminality of an act, mitigates the punishment or otherwise improves the position of a person, i.e.it applies to persons who committed the relevant act before the entry into force of such a law, including persons who are serving or have served a sentence, but with a criminal record. The new law will not have retroactive effect if it criminalizes the act, increases the punishment, or otherwise worsens the position of a person.

\section{Main Part} include:
1. Constitution of 1949 of the Federal Republic of Germany, which contains a number of principles of a criminal-legal nature: these are provisions on the retroactive force of the law, on the inadmissibility of punishment multiple times for the same act, on the admissibility of imprisonment only on the basis of the law and by a court decision, on the abolition of the death penalty.

2. Constitution of Lands - subjects of the federation, whose competence includes regulation of issues of a criminal-legal nature. The federal legislator intervenes in the field of criminal law in cases of the need for uniform regulation of a particular issue throughout Germany. The determination of these issues is within the competence of the federal legislator.

3. Criminal Code of 1871, which has undergone a number of stage-by-stage significant changes, defined as reforms of criminal law. German lawyers distinguish six such stages according to the periods of 
development of the German state from the end of the 19th century.

4. Additional criminal legislation, which includes acts of criminal law content that did not entail changes to the Criminal Code, containing norms of a public and private law nature. These are the laws of economic, monetary regulation, on the protection of consumer rights, on the protection of public order. For example, the Law on Facilitating the Fight against Illegal Work of 2002, the Migration Law of 2004.

5. Criminal legislation of the subjects of the Federal Republic of Germany - lands. The Federal Republic of Germany includes sixteen lands.

6. German Code of Crimes against International Law on January 26, 2002[2. $11]$.

Most of the criminal legislation of the Federal Republic of Germanyis reflected in the Criminal Code[3. 256].

First title of Criminal Code [4] (Strafgesetzbuch - StGB)established rules for the application of criminal law in time, space and in persons. The rules for action in time are set out in paragraphs $1-2,8$ of this title.

According to Section 1 "An act may only be punished if criminal liability had been established by law before the act was committed". This rule is an expression of the principle of legality (nullum crimen sine lege, nulla poena sine lege), enshrined in paragraph 2 of Article 103 of the Basic Law -the Constitution of Germany.

Section 2 entitled " Jurisdiction ratione temporis; lex mitior|, consists of 6 subsections as follows: 1 . The penalty and any ancillary measures shall be determined by the law which is in forceat the time of the act. 2. If the penalty is amended during the commission of the act, the law in force at the timethe act is completed shall be applied. 3 . If the law in force at the time of the completion of the act is amended before judgment, the most lenient law shall be applied. 4. A law intended to be in force only for a determinate time shall be continued to be applied to acts committed while it was in force even after it ceases to be in force, unless otherwise provided by law. 5. Subsections (1) to (4) shall apply mutatis mutandis to confiscation, deprivation and destruction. 6. Unless otherwise provided by law, measures of rehabilitation and incapacitation shall be determined according to the law in force at the time of the decision.

As it is established in Section 8 (Time of the offence) "An offence is deemed to have been committed at the time when the principal or the secondary participants acted, or, in the case of an omission, should have acted. The time when the result occurs is irrelevant."

So, according to the German Penal Code:

1) the criminal legislation establishing criminality of the act, has no retroactive force;

2) the more lenient, including "intermediate" criminal law, has retroactive effect, provided that the limits of its application are limited by the time of the adoption of the law enforcement act;

3) the "temporary" criminal law, that is, the law adopted for a certain period of time, applies to all acts committed during its validity.

4) the criminal law governing corrective and security measures shall be determined by the law in force at the time of the decision, unless otherwise provided by the criminal law.

The sources of criminal law in modern France include:

1. The Declaration of the Rights of Man and of the Citizen from August 26, 1789 - the most important document of the era of the Great French bourgeois revolution, which laid down the principles for the development of legislation that followed after the collapse of feudalism and the feudal system of law.

The declaration contained constitutional norms that were fundamental 
for the constitutional development of France. The Declaration contains provisions that are directly related to criminal legislation.

These are primarily the provisions of Art. 5: "Anything which is not forbidden by the law cannot be impeded, and no one can be constrained to do what it does not order"; Art. 7: "No man can be accused, arrested nor detained but in the cases determined by the law, and according to the forms which it has prescribed."; Art. 6: " It must be the same for all, either that it protects, or that it punishes."

The Declaration enshrines the principle of the presumption of innocence: "Any man being presumed innocent until he is declared culpable", another important principle: "No one may be disquieted for his opinions, even religious ones, provided that their manifestation does not trouble the public order established by the law".

These and other principles have become the property of not only French legislation, they are, in one form or another, as their own principles enshrined in the constitutions of many states of the world and the criminal codes adopted on their basis.

2. French Constitution of October 4, 1958. It recognizes the the Declaration of the Rights of Man and of the Citizen of 1789 as an integral part of the Constitution. The constitution enshrines the president's right to pardon.

3. International agreements. Article 55 of the Constitution recognizes the primacy of international law over domestic law. This principle is manifested in the fact that the legislator cannot pass laws that would contradict the provisions of an international treaty or convention.

Existing international agreements as sources of criminal law relate mainly to the problems of extradition, the provision of legal assistance, the fight against certain types of crimes provided for by the conventions, the provisions of some of them are included in the French Criminal Code.
4. French Criminal Code of 1992. It was adopted in early 1992 and entered into force on March 1, 1994, replacing Napoleon's Penal Code of 1810. The adoption of the new Criminal Code was due to the modern level of lawmaking, the recognition of the protection of human rights and freedoms as a priority task for all mankind, the consistent implementation of the principle of the primacy of international law over national law in order to eliminate emerging contradictions, and the state's response to the emergence of new types of serious and dangerous crimes.

5. Code of Criminal Procedure (CPC) of France of 1958. The Criminal Procedure Code enshrines the principle prohibiting twice punishment for the same crime, and also includes provisions on conditional conviction, sets the terms for criminal prosecution and execution of a conviction for certain types of criminal acts.

6. Other codes. France is a state that strictly adheres to the principle of codification of legislation, therefore the system of law is formed by a large number of narrow-branch codes. Some of them contain norms of a criminal-legal nature, in particular, the Code of Military Justice, which establishes criminal liability for military crimes, the Customs Code, the Labor Code, the Road Code, etc.

7. Laws as sources of criminal law: Law on Commercial Companies of 1966, Law on Commercial Partnerships of 1966, etc.

8. By-laws adopted by state executive authorities, for example, the Provisional Government Ordinance "On the Prosecution of War Crimes" of August 28, 1944, Ordinance No. 45-174 of February 2, 1945 on juvenile offenders, etc[5. 11].

The main source of French criminal law is the Criminal Code (Code pénal[6]). Chapter 2 "Application of criminal law in time"(Articles 112-1-112-4) of the Criminal Code regulates issues related to the application of the criminal law in time. 


\section{Results and Discussion}

It should be noted that on the question of the operation of the criminal law in time in the criminal law doctrine of France, two main concepts collide: the classical one, called the Merle-Levasseur system, and the "new" one, called the Rubier-Vitu system.In accordance with the classical concept, the new criminal law has no retroactive effect. This provision logically follows from the principle of legality. The latter is defined in French criminal law as a rule, according to which no one can be prosecuted except on the basis of a law issued before the commission of a criminal act. According to this concept, the retroactive effect of the criminal law is only an exception to the general rule (for example, the retroactive effect of a milder criminal law). Consequently, all doubts should be interpreted in favor of the non-application of the new criminal law to criminal acts committed before its entry into force.

According to another concept, as principle should be recognized the direct application of the new criminal law to all acts that, although committed before the publication of this law, were not considered finally by the court and the verdict on them did not come into legal force, since it is assumed that the new law is always superior in legal force to the old. So, the supporters of the second concept, unlike the first, believe that the direct application of the new criminal law should become the rule, and its inaction is only an exception to the rule. Consequently, all doubts must be interpreted in favor of the application of the new criminal law [7. 308].

According to article 112-1 of the French Penal Code, actions are punishable only where they constituted a criminal offence at the time when they took place.Only those penalties legally applicable at the same date may be imposed. However, new provisions are applicable to offences committed before their coming into force and which have not led to a res judicata conviction, when they are less severe than the previous provisions.It follows that in the absence of a verdict that has entered into legal force, the milder law will have retroactive effect.

In the next section 112-2, the following laws apply immediately to criminal cases committed prior to their entry into force: 1) laws governing jurisdiction and judicial organisation, provided no first instance judgment on the issue has been pronounced; 2) laws determining the modes of prosecution and procedural formalities; 3 ) laws governing the execution and enforcement of penalties; however, where they would result in making the penalties imposed by the sentence harsher, such laws will only be applicable to offences committed after their coming into force; 4) where the limitation period has not expired, laws governing the limitation of the public prosecution and the limitation of penalties.

According to article 112-3 laws governing the type and availability of means of review, as well as time-limits within which they are to be instituted and the legal capacity of persons allowed to apply are applicable to remedies sought against decisions passed after their coming into force. Remedies are covered by rules as to formalities which are in force at the time they are sought.

Due to the last article 112-4 the immediate application of a new law shall not affect the validity of procedural steps carried out in accordance with any previous law. However, the penalty ceases to be enforceable where it was imposed for a matter which, in consequence of any law enacted after the judgment was passed, no longer amounts to a criminal offence.It follows that if the new law simply reduces the punishment and improves the person's condition in a different way, this will not in any way affect the fate of the convicted person.

Consequently, it is clear from these articles that both substantive and procedural law are reflected here, which implies the specifics of French criminal law. A criminal act shall be subject to the criminal law in force at the time of its commission. The 
following are retroactive: 1) laws with lighter provisions (in the absence of an effective court decision on the case under consideration); 2) laws on the execution of punishments (not aggravating the situation of the convicted person); 3) laws on the terms of prosecution and execution of the sentence (if these terms have not expired).

\section{Conclusion}

Based on the foregoing, it can be said that the criminal law of the analyzed countries specifically addresses issues related to the institution of temporal application of criminal law. Effective use of the existing legislative experience of these countries will help resolve some issues related to the institution of the application criminal law in time, improve the institution as a whole, and ensure the principles of legality, justice and humanity.

From this point of view, it is proposed to take into account the following when improving the provisions of Article 13 of the Criminal Code of the Republic of Uzbekistan, which regulates the operation of the criminal law in time: to clarify which criminal law applies to other legal consequences, i.e. determine the applicable criminal law as "at the time of the commission of the crime", "at the time of the onset of these consequences" or "at the time of the resolution of the case"; reconsider the time of commission of crime.

\section{References}

[1] The Criminal Code of the Republic of

Uzbekistan.

\section{https://lex.uz/docs/111453}

[2] Criminal law of foreign countries: textbook / LS Aistova, D. Yu. Kraev. - 2nd ed. / revised from the 1st edition by D. Yu. Kraev - St. Petersburg: St. Petersburg Law Institute (branch) of the University of the Prosecutor's Office of the Russian Federation, 2020. - p.11.

[3] The Handbook of Comparative Criminal Law. Kevin Jon Heller, Markus Dubber. Stanford University Press, 2010. P.256.
[4] Criminal Code in the version promulgated on 13 November 1998, Federal Law Gazette[Bundesgesetzblatt] I p. 3322, last amended by Article 1 of the Law of 24 September 2013,Federal Law Gazette I p. 3671 and with the text of Article 6(18) of the Law of 10 October2013, Federal Law Gazette I p 3799.https://www.legislationline.org/ download/id/6115/file/Germany_CC am2013_en.pdf

[5] Criminal law of foreign countries: textbook / LS Aistova, D. Yu. Kraev. - 2nd ed. / revised from the 1st edition by D. Yu. Kraev - St. Petersburg: St. Petersburg Law Institute (branch) of the University of the Prosecutor's Office of the Russian Federation, 2020. - p. 11

[6] https://www.legislationline.org/down load/id/8546/file/France_CC_am012 020_fr.pdf. The current version of the French Criminal Code consists of 2 parts, part 1 was adopted on July 22, 1992, and part 2 - on March 29, 1993. The Code entered into force on March 1, 1994. Prior to this code, the Napoleonic Code of 1810 was in force.

[7] Criminal law of foreign countries. General and Special parts: textbook / ed. I. D. Kozochkin. - 3rd ed., Rev. and add. - M .: Voltere Kluver, 2010. -p. 308.

[8] Features of legal regulation of investors activity in the territory of free economic zones. M Qurbonov Review of law sciences, 2017 